\title{
Fire lines as fault lines: increased trade barriers during the COVID-19 pandemic further shatter the global food system
}

\author{
Kevin Z. Chen ${ }^{1,2} \cdot$ Rui Mao ${ }^{1}$ \\ Received: 13 May 2020 / Accepted: 30 June 2020 / Published online: 8 July 2020 \\ (C) International Society for Plant Pathology and Springer Nature B.V. 2020
}

\begin{abstract}
In this opinion piece, we highlight that trade barriers established during COVID-19 as "fire lines" to prevent cross-border transmission of the pandemic could become "fault lines" that demolish the global food system. We review restrictions on both international agricultural exports and imports, especially unilateral border controls such as import refusals and alerts, in previous epidemics and arising with two novel features amid COVID-19. Institutional causes to pervasive trade barriers in epidemics that are embedded in the WHO-WTO coordination scheme have been discussed. In the meantime, discussions on potential economic outcomes and policy recommendations have been provided.
\end{abstract}

Keywords Global food system · Trade barriers $\cdot$ Border controls $\cdot$ COVID-19

The current global food system is more integrated than ever. However, the risk that this system will shatter exists, as the effects of COVID-19 have rippled through it. During January and February, when the pandemic was mostly confined to mainland China, China's total export value, compared with that of the same period during the previous year, plunged by $17.2 \%$, and the export value of its agricultural products plunged by $11.6 \%$ (GACC 2020a, b). Although the worldwide impacts of this crisis are still invisible in most trade statistics, leading indices such as Purchasing Managers' Indexes (PMIs) suggest that severe trade contractions will emerge. The WTO predicted that global trade would decline by $13-32 \%$ in 2020 , which, in the worst case, could reach a new low since the global financial crisis (WTO 2020). International agricultural trade is also likely to stumble. In fact, Chinese purchase orders of US farm products were reduced during the first two months of this crisis, and Moroccan orders of these products were indefinitely postponed in March (USDA FAS 2020; Virginia Tech 2020). The strain faced by

Rui Mao

rmao@zju.edu.cn

Kevin Z. Chen

kzchen@zju.edu.cn

1 China Academy for Rural Development (CARD), Zhejiang University, Hangzhou, China

2 International Food Policy Research Institute (IFPRI), Beijing, China logistics systems during this pandemic is a key factor behind trade contractions, since disruptions in transportation have made the delivery of farm goods difficult (Torero 2020b). Yield cuts are expected in certain regions and sectors due to labor shortages and limited input access, which dim the outlook of agricultural trade (Torero 2020a).

In addition to the stresses faced by the supply side, the establishment of tightened border controls in the case of international agricultural trade may further shatter the global food system. The WHO and FAO have invoked the need for free trade, as there is no evidence that suggests that the virus spreads through food products (WHO 2020). Historically, however, strict border controls have often been observed for agricultural exports originating from affected regions. For example, Indonesia, Korea and Russia issued import prohibitions on both wild and live animals as well as animalderived products from China in January and February, whereas Egypt forbade imports of garlic, carrots and green ginger from China (ATPC 2020). With the rapid spread of the COVID-19 pandemic to other regions, a number of countries, such as Mauritius, have restricted imports of animal goods from China, Iran, Korea, Switzerland and the EU since March, while Vietnam established a complete import ban on wild animals and any related products from around the world (ITC 2020). Additionally, Iraq and Seychelles increased their import duties on agricultural products (ITC 2020). Aside from these import measures that the WTO was advised of, countries also adopted unilateral border controls by refusing entry to 
specific imports. The total number of import refusals of the US Food and Drug Administration (FDA) against agricultural products, for instance, increased by $52 \%$ in January and $27 \%$ in the first quarter of 2020 over the previous year, both representing the highest year-over-year growth rate since 2002 (FDA 2020b). In particular, the FDA increased its import refusals of agricultural exports from China, where this pandemic first began. The number of FDA import refusals of Chinese agricultural exports rose by $84 \%$ in January over the previous year, which led China's share in the overall FDA refusals of agricultural products higher by $50 \%$ (FDA 2020b). Since the FDA enjoys considerable discretion in making such decisions in accordance with the Federal Food, Drug, and Cosmetic Act (FDA 2020a), import refusals could be used as an effective tool for the purpose of trade protection during economic or sectoral downturns (Grundke and Moser 2019; Jouanjean et al. 2015). Food safety authorities may also use import refusals as a means to prevent a pandemic from spreading through trade. In fact, increased refusals and alert incidents imposed by the FDA and the national food safety authorities of the EU member states involving imports from affected regions were also observed during previous epidemics such as Ebola, H1N1 and SARS (EC 2020).

Increased border controls on agricultural trade during epidemics reflect the ineffectiveness of the WTO and the WHO in the context of trade regulation. One critical reason for this issue is the lack of formal coordination between the WHO and the WTO, which has been a problem for some time, regarding the prevention of cross-border transmission of epidemics. While both the WHO and the WTO abide by the principle of minimizing adverse impacts on international traffic and trade through the control of epidemics and acknowledge the justification of trade restrictions only in certain conditions with the strong support of scientific proof, their judgments regarding specific measures often differ. For example, Mexico appealed to the WTO in reference to trade restrictions that had been imposed on the country by other countries during the H1N1 pandemic, referencing statements made by the WHO and FAO saying that such actions have "no justification in the OIE Terrestrial Animal Health Standards Code", but this appeal failed after prolonged debates (WTO 2009). A fundamental reason for such disputes is that the epidemic alerts and severity assessments provided by the WHO are not directly linked to the use of trade measures within the WTO's framework. The WTO primarily considers trade-related measures related to public health concerns based on two agreements, namely, the agreement on sanitary and phytosanitary measures (SPS) and that on technical barriers to trade (TBT). Nevertheless, a declaration of a Public Health Emergency of International Concern by the WHO does not constitute a specific condition in which these measures should be activated. This issue typically leads to the implementation of excessive trade restrictions during epidemics, since judicial obscurity can become an obstacle to the appeals made by affected regions, as can be observed in the aforementioned case involving Mexico. Moreover, it is interesting to observe that public health experts from the WHO are rarely involved in the reviews of epidemic-related trade policies performed by WTO committees (Giesecke 2003).

Regarding the COVID-19 pandemic, however, two additional observations are noted apart from increased border controls. The first is that once established, trade barriers implemented against affected regions might remain in place for a long time, even after infections are controlled, as long as the spread of infection still persists elsewhere. For instance, none of the temporary trade measures against Chinese exports that the WTO was advised of during the pandemic have been lifted, although the country announced on March 12 that the peak of COVID-19 in its region was over (Xinhua 2020). Even after this announcement, the FDA's import refusals of Chinese agricultural exports during March to May increased by more than $38 \%$ over the previous year. Second, trade barriers are implemented not only by countries that receive imports against the exports from coronavirus-affected regions but also by exporters on vital food products such as grain. Between March 20 and April 10,20 countries established limits or bans on various food exports including rice, wheat, oil, fruit, vegetables and eggs; most of these limitations were in reference to domestic food security concerns, and only half of them had a specified end date (ITC 2020).

Increased obstacles to both the supply and the demand within the global food system imply that food surpluses and deficits will likely be observed simultaneously in various sectors and regions around the world. Such obstacles demonstrate that the trade protectionism that emerges during pandemics is either motivated by attempts to mitigate impacts on domestic industries or those on citizens; however, both of these types of protectionism can result in devastating consequences, usually to the most vulnerable stakeholders in the global food system. On the one hand, countries might reinforce trade protections to support industries that are suffering from logistic strains or decreased demand due to the competition of imports. These protections might threaten the livelihoods of the related producers in the exporting countries, especially those of small farmers; this effect has been felt in China's aquaculture industry since March (Zhang 2020). On the other hand, trade protections in the form of export restrictions make access to the global market more difficult, which could result in a food security crisis, particularly in the cases of the least developed nations where these issues are already acute (Rutten et al. 2013). 
To prevent trade barriers established as "fire lines" in the name of pandemic control from becoming "fault lines" that may demolish the global food system, a number of policy options can be considered. First, individual countries should avoid the temptation to enact additional border control measures. In particular, they need to collaborate in the limitation of discretionary decisions regarding import refusals and alerts and align these decisions with WTO principles by applying the requirements regarding the sufficient support of scientific evidence and a high level of information transparency involving such evidence in the case of affected exporters. Second, a formal WHO-WTO coordination system needs to be established to conduct reviews and assessments of the trade measures imposed during an outbreak. This system will be of particular importance to the least developed countries that have a high level of dependency on overseas food sources. By increasing the incorporation of the voices of public health and food policy experts, the system will allow reviews on whether export bans and limitations on vital agricultural products imposed by major food exporters are unnecessary. Finally, it is critical that agricultural exporters from the least developed countries build a capacity for quality enhancement, especially by adopting food safety regulations that are compatible with mainstream international standards. Import barriers during pandemics often occur outside the WTO framework, as they are manifested by import refusals and alerts. Upgrades in product quality can help exporters from developing countries to overcome these barriers (Zhou et al. 2019). High-quality products accompanied by strong brands and product standardization alleviate consumer concerns regarding pandemic hazards and thus reduce the demand-side vulnerabilities of the food system.

Funding information This study was financially supported by the National Science Foundation of China (NSFC), Project No. 71873119; Ministry of Education of China, Project No. 19JHQ060; Zhejiang University-IFPRI Center for International Development Studies (Grant 126,000-541,902); and the CTF Young Scholar Fund.

Data Availability Not applicable.

Code availability Not applicable.

\section{Compliance with ethical standards}

Conflicts of interest/competing interests The authors declared that they have no conflict of interest.

\section{References}

Agricultural Trade Promotion Center, Ministry of Agriculture and Rural Affairs of the People's Republic of China (ATPC). (2020). Analysis of technical trade measures in COVID-19 adopted by exporting markets on China's agricultural products. Retrieved from: https:// mp.weixin.qq.com/s/rPZt-4m8gpgKzu3ShG0phA.

European Commission (EC). (2020). RASFF portal. Retrieved from: https://ec.europa.eu/food/safety/rasff/portal_en.

Food and Drug Administration (FDA). (2020a). Import basics. Retrieved from: https://www.fda.gov/industry/import-program-food-anddrug-administration-fda/import-basics.

Food and Drug Administration (FDA). (2020b). Import refusals. Retrieved from: https://datadashboard.fda.gov/ora/cd/imprefusals. htm.

General Administration of Customs of the People's Republic of China (GACC). (2020a). China's Major Exports by Quantity and Value, January-February 2020 (in USD). Retrieved from: http://english. customs.gov.cn/Statics/2ae83fa1-7598-46b8-9571-3aa173bbcbcc. html.

General Administration of Customs of the People's Republic of China (GACC). (2020b). China's Total Export \& Import Values, JanuaryFebruary 2020 (in USD). Retrieved from: http://english.customs. gov.cn/Statics/6c376734-a6b1-4b14-83c6-5a3ba61c5893.html.

Giesecke, J. (2003). International health regulations and epidemic control. In R. Smith, R. Beaglehole, D. Woodward, \& N. Drager (Eds.), Global public goods for health: Health economic and public health perspectives (pp. 196-211). Oxford: Oxford University Press.

Grundke, R., \& Moser, C. (2019). Hidden protectionism? Evidence from non-tariff barriers to trade in the United States. Journal of International Economics, 117, 143-157.

International Trade Centre (ITC). (2020). COVID-19 temporary trade measures. Retrieved from: https://www.macmap.org/covid19.

Jouanjean, M. A., Maur, J. C., \& Shepherd, B. (2015). Reputation matters: Spillover effects for developing countries in the enforcement of US food safety measures. Food Policy, 55, 81-91.

Rutten, M., Shutes, L., \& Meijerink, G. (2013). Sit down at the ball game: How trade barriers make the world less food secure. Food Policy, $38,1-10$.

Torero, M. (2020a). COVID-19 and the risk to food supply chains: How to respond? FAO. http://www.fao.org/3/ca8388en/CA8388EN.pdf. Accessed 25 April 2020.

Torero, M. (2020b). Without food, there can be no exit from the pandemic. Nature, $580,588-589$.

United States Department of Agriculture Foreign Agricultural Service (USDA FAS). (2020). North Africa - March 2020. Retrieved from: https://www.fas.usda.gov/topics/north-africa-march-2020.

Virginia Tech. (2020). COVID-19 could alter agricultural trade relationships; change view of globalization and interdependency for food. Retrieved from: https://vtnews.vt.edu/articles/2020/04/ agriculturetrade_expert.html.

World Health Organization (WHO). (2020). Updated WHO recommendations for international traffic in relation to COVID-19 outbreak. Retrieved from: https:/www.who.int/news-room/articles-detail/ updated-who-recommendations-for-international-traffic-in-relationto-covid-19-outbreak.

World Trade Organization (WTO). (2009). T Members discuss trade responses to H1N1 flu. Retrieved from: https:/www.wto.org/ english/news_e/news09_e/sps_25jun09_e.htm.

World Trade Organization (WTO). (2020). Trade set to plunge as COVID-19 pandemic upends global economy. Press Release, PRESS/855.

Xinhua. (2020). China says its COVID-19 peak is over. Retrieved from: http://www.xinhuanet.com/english/2020-03/12/c_138870547.htm.

Zhang, C. (2020). Changes of China's sustainable aquaculture amid the pandemic. Retrieved from: https://chinadialogueocean.net/13453coronavirus-hits-sustainable-aquaculture/?lang=zh-hans.

Zhou, J., Wang, Y., \& Mao, R. (2019). Dynamic and spillover effects of USA import refusals on China's agricultural trade: Evidence from monthly data. Agricultural Economics / Zemedelska Ekonomika, 65(9), 425-434. 


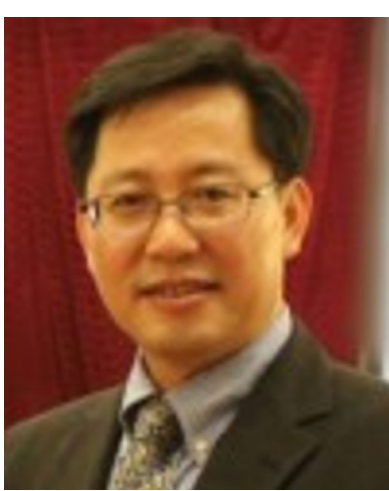

Dr. Kevin Z. Chen : is Qiushi Chair Professor in School of Public Affairs at Zhejiang University and is also the International Dean of China Academy for Rural Development (CARD). He is Editor-in-Chief of International Food and Agribusiness Management Review and Co-Editor of China Agricultural Economic Review. $\mathrm{He}$ is also a member of global independent expert group (IEG) of Global Nutrition Report (GNR). Dr. Chen was an associate professor (Tenured) at the Department of Resource Economics and Sociology at the University of Alberta and co-editor for Canadian Journal of Agricultural Economics. He has conducted over 30 projects supported by Bill \& Melinda Gates Foundation, the World Bank Group, UK Department for International Development, Asia Development Bank, World Food Programme, Canadian International Development Agency, and Natural Science Foundation of China. During 2005-2009, Dr. Chen led a mega CIDA-funded agricultural development project in China, which also won 'Sang Nong People of the Year'at CCTV7 in 2008. In recent years, Dr. Chen mainly focuses his research interest on agricultural industry organization, agri-food supply chain governance, economic transformation and agricultural development strategy, food system modeling, poverty alleviation and South-South cooperation on agriculture.

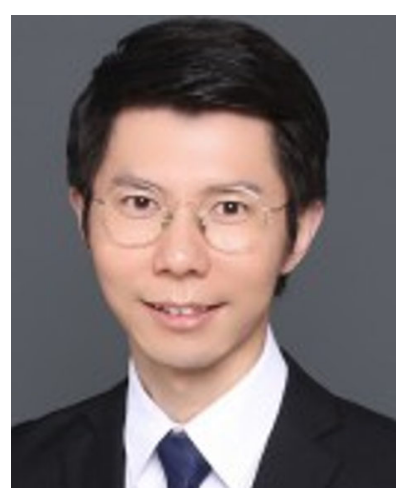

Dr. Rui Mao : is Professor in School of Public Affairs and China Academy for Rural Development (CARD) of Zhejiang University. $\mathrm{He}$ is "Chung Ying Distinguished Young Scholar" and "Qiushi Outstanding Young Scholar". He is also Assistant Dean of CARD and Associate Chair of Department of Agricultural Economics. He now serves a s M a n a ing Editor of International Food and Agribusiness Management Review. He earned BA in finance, BS in mathematics, and $\mathrm{PhD}$ in economics from Peking University. He was award the seventh "MundellHuang Prize on Economics". His research field includes economic growth and structural change, international trade and finance, and rural development. 